\title{
CHARACTERIZATION AND IN VITRO EXPRESSION OF THE CYTOCHROME $b$-559 GENES OF BARLEY I. LOCALIZATION AND SEQUENCE OF THE GENES
}

\author{
by \\ KARIN KRUPINSKA ${ }^{1)}$ and SANDY BERRY-LOWE ${ }^{2)}$ \\ Department of Physiology, Carlsberg Laboratory, \\ Gamie Carlsberg Vej 10, DK-2500 Copenhagen Valby \\ 1) Present address: Botanisches Institut der Universität Kiel, \\ Olshausenstr. 40-60, D-2300 Kiel, FRG \\ 2) Present address: Department of Botany, University of Georgia, \\ Athens, GA 30602, USA
}

Keywords: Chloroplast DNA, cytochrome $b-559$ apoproteins, transcript, psbE, psbF

The psbE and psbF genes encoding the 9.4 and $4.4 \mathrm{kD}$ apoproteins of cytochrome $b-559$ have been located in the chloroplast genome of barley. As in other plant species they are found adjacent to each other in the large single copy region of the chloroplast DNA. Both the nucleotide sequence and the deduced amino acid sequence for the two polypeptides are identical to that of wheat and more than $95 \%$ similar to those of spinach, tobacco and Oenothera. The region between the two genes spans 10 nucleotides (excluding the stopcodon) and contains a typical procaryotic ribosomal binding site. A dicistronic transcript is identified, but the presence of a ribosomal binding site between the two genes may allow independent translation.

\section{INTRODUCTION}

Cytochrome $b-559$ is an ubiquitous component of photosystem II in the thylakoid membranes of higher plants and algae. To date the physiological role of this cytochrome and its multiple redox potential forms in photosynthesis remains unknown. While apparently not being a member in the main electron transport chain from water to NADP it can participate in cyclic electron transport around photosystem II. These aspects and possible functions in the water-splitting activity of photosystem II are summarized and discussed by CRAMER et al. (7). Recent dissection of the composition of photosystem II reveals cytochrome $b-559$ to be closely associated with the D1 and D2 proteins in the photosystem II reaction center core (18).

Cytochrome $b-559$ can be isolated from thy-

Abbreviations: $\mathrm{bp}=$ basepairs; $\mathrm{cp}$ DNA = chloroplast DNA; $\mathrm{kbp}=$ kilobasepairs; $\mathrm{kD}=$ kilodalton; $\mathrm{SDS}=$ sodium dodecyl sulfate; $\mathrm{SSC}=0.15 \mathrm{M}$-sodium chloride $+0.015 \mathrm{M}$-sodium citrate; Tris $=$ tris-(hydroxymethyl)aminomethane. 
lakoid membranes as a lipoprotein complex with an apparent molecular weight of $110 \mathrm{kD}$ (28). Dissociation of the complex under mild conditions yields subunits of about $30 \mathrm{kD}$ that still contain heme (15). After complete denaturation of the complex a $9-10 \mathrm{kD}$ polypeptide is obtained and this polypeptide can be synthesized in isolated chloroplasts (32).

The gene coding for the apoprotein was localized on the chloroplast genome of spinach (29) and its nucleotide sequence determined (12). The deduced amino acid sequence was shown to be consistent with the $\mathrm{N}$-terminal amino acid sequence of the $9.4 \mathrm{kD}$ polypeptide (30). The gene is named psbE and is bicistronically transcribed together with another gene located 3' downstream of psbE. This gene, psbF, is separated from psbE by only 8 nucleotides and codes potentially for a $4.4 \mathrm{kD}$ polypeptide (12). Subsequently, it was shown that a polypeptide of this size indeed is an additional component of the cytochrome $b-559$ complex (31). Hitherto, only the well-known $9 \mathrm{kD}$ protein has been detected in isolated photosystem II preparations $(2,18)$. Meanwhile the psbE- and psbF genes have been sequenced in Oenothera hookeri, Nicotiana tabacum (5) and wheat (13). More than 95\% conservation of the nucleotide sequences is observed among the four species.

The molecular arrangement of the apoproteins and heme groups within the oligomeric complex is not yet known. Spectroscopic data indicate a biaxial ligation of heme within the complex (1). The $9.4 \mathrm{kD}$ and the $4.4 \mathrm{kD}$ polypeptides contain each one histidine residue which could bind coordinatively to heme. Models of homodimers or heterodimers as the smallest heme containing subunits of cytochrome $b-559$ have been proposed (12). However, these models hardly give an understanding of the molecular organization of the $110 \mathrm{kD}$ complex containing only one heme molecule per protein moiety of $30-46 \mathrm{kD}(15,28)$.

The in vitro assembly of the complex by starting from the in vitro translation products of the cloned genes might provide an alternative approach to clarify whether both apoproteins are necessary to form a functional cytochrome $b-559$ and how these apoproteins are linked in the complex. Towards this end, the psbE and
psbF genes have been localized on the chloroplast DNA of barley and their nucleotide sequence has been determined. In a forthcoming paper (of this journal) the in vitro expression of the genes is analyzed by coupled transcription and translation.

\section{MATERIALS AND METHODS}

\subsection{Cloned cp DNA and plasmids}

Cloned chloroplast DNA (cp DNA) of barley was provided by C. POULSEN. PstI fragments derived from barley cp DNA had been ligated into the PstI site of the gene providing ampicillin resistence in pBR325, while HindIII fragments had been ligated into the gene of pBR322 giving tetracycline resistance (19). The plasmid pUC13 (27) was used for subcloning of cp DNA-fragments derived from the larger PstI- and HindIII fragments. PUC13 contains the bla-gene for $\beta$-lactamase conferring ampicillin resistance to the bacterial host.

\subsection{Strains and media}

E. coli JM83 was used in all cloning experiments with pUC13. The recipient strain for the recombinant $\mathrm{pBR} 322$ and $\mathrm{pBR} 325$ clones was E. coli HB101 (19).

Bacteria containing recombinant pUC13 plasmids were grown on LB medium ( $1 \%(\mathrm{w} / \mathrm{v})$ Difco Bactotryptone, 0.5\% (w/v) Difco Bactoyeast, $1 \%(\mathrm{w} / \mathrm{v})$ sodium chloride) supplied with ampicillin $\left(100 \mu \mathrm{g} \times \mathrm{ml}^{-1}\right)$ and appropriate for screening with $50 \mu \mathrm{g} \times \mathrm{ml}^{-1}$ of 5-bromo-4 chloro-3 indolyl- $\beta$ D-galactopyranoside (X-gal). For bacteria containing recombinant pBR322 or pBR325 plasmids minimal medium (17) supplied with $0.4 \%(\mathrm{w} / \mathrm{v})$ casamino acids and containing tetracycline $\left(12.5 \mu \mathrm{g} \times \mathrm{ml}^{-1}\right)$ or ampicillin (100 $\mu \mathrm{g} \times \mathrm{ml}^{-1}$ ), respectively, was found to be more appropriate than LB medium.

\subsection{Chemicals and enzymes}

All chemicals used were of analytical grade. Low melting agarose used in cloning experiments was from Litex, Copenhagen. Bal 31 exonuclease was purchased from IBI, Newhaven, Conn, USA. All other enzymes were from 
Boehringer, Mannheim, FRG. Radioactive nucleotides were obtained from New England Nuclear, USA.

\subsection{Transformation}

E. coli cells were grown and prepared for transformation by standard methods (17). Competent cells were stored in $0.1 \mathrm{M}-\mathrm{CaCl}_{2}$ including $14 \%(\mathrm{v} / \mathrm{v})$ glycerol at $-80^{\circ} \mathrm{C}$. Transformants were selected for ampicillin resistance.

\subsection{Isolation and purification of DNA}

For size screening of recombinant plasmids, cells of $1 \mathrm{ml}$ overnight cultures were resuspended in $100 \mu \mathrm{l}$ of a solution consisting of 0.3 M-sucrose, $25 \mathrm{~mm}$-Tris/HCl, pH 8.0, 25 mMEDTA and $0.02 \%(w / v)$ bromophenolblue. After addition of $50 \mu \mathrm{l}$ of $0.3 \mathrm{M}-\mathrm{NaOH}$ and $2 \%$ (w/v) SDS the cells were lysed at $70{ }^{\circ} \mathrm{C}$ for 20 minutes. After a single extraction with $20 \mu \mathrm{l}$ of a phenol/chloroform mixture $(1: 1)$ the DNA containing solution was directly analyzed on $1 \%$ $(w / v)$ agarose gels.

More pure, digestable plasmid DNA was prepared on small scale according to HATTORI and SAKAKI (11). For preparing large amounts of plasmid DNA from $250 \mathrm{ml}-1 \mathrm{l}$ cultures the method of BIRNBOIM and DOLY (4) followed by $\mathrm{CsCl}$-equilibrium centrifugation (20) was used.

Individual DNA-fragments used in cloning experiments were isolated from low melting agarose gels by heating of the gel piece in an equal volume of $100 \mathrm{~mm}$-Tris/ $\mathrm{HCl} \mathrm{pH} 8.0 \mathrm{buffer}$ containing $10 \mathrm{~mm}$-EDTA at $70{ }^{\circ} \mathrm{C}$ for $10 \mathrm{~min}$ utes, followed by a twofold extraction with phenol and a threefold extraction with ether before ethanol precipitation.

Large amounts of DNA-fragments were isolated from preparative agarose gels by electroelution into dialysis bags using a $60 \mathrm{~mm}$-Trisbuffer containing $2 \mathrm{mM}$-EDTA and adjusted to $\mathrm{pH} 8.3$ with acetic acid.

\subsection{DNA endonuclease restriction site mapping}

Restriction sites of endonucleases were mapped on DNA-fragments according to SMITH and BIRNSTIEL (24). Following their procedure the fragments were labelled with ${ }^{32} \mathrm{P}$ at both ends by filling in nucleotides with Klenow enzyme, and then cleaved with an appropriate restriction enzyme into two asymmetrical subfragments. The two resulting fragments were separated on agarose gels and after electroelution partially digested with the relevant enzyme. The lengths of the products with a common labelled terminus correspond directly to the positions of restriction sites along the DNA-fragments.

\subsection{DNA-sequencing}

Chloroplast DNA-fragments were sequenced after subcloning into pUC13 with the dideoxychain-termination method of SANGER et al. (22) using direct and reverse primers. Plasmid DNA was denatured in $0.2 \mathrm{M}-\mathrm{NaOH}$ before annealing with the primer (6). The radioactive label was $\alpha-{ }^{35}$ S-dATP $\left(18.5 \times 10^{12} \mathrm{~Bq} \times \mathrm{mmol}^{-1}\right)$. The dried gels were exposed to Kodak XRP1 films for 2-3 days.

\subsection{Analysis of DNA by hybridization to radioactive DNA-probes}

After digestion of large cpDNA-fragments cloned into pBR322 or pBR325 the subfragments were electrophoretically separated on $0.8-1.0 \%(\mathrm{w} / \mathrm{v})$ agarose gels and transferred to nitrocellulose according to the method of Southern (25). Synthetic oligonucleotides complementary to sequences in the non-transcribed strand of the psbE and psbF genes of spinach (12) were prepared on an Applied Biosystems Oligonucleotide Synthesizer and used as probes. One probe covers amino acid residues 17-22 of the $9.4 \mathrm{kD}$ apoprotein including the histidine residue. The second probe covers amino acid residues $14-19$ of the $4.4 \mathrm{kD}$ apoprotein including the histidine residue of this polypeptide. The oligonucleotides were labelled with ${ }^{32} \mathrm{P}$ by polynucleotide kinase.

For comparison, hybridizations were carried out with heterologous DNA from spinach (clones pCYb 559/1 and pCYb 559/2, kindly provided by Professor R.G. HeRRMANN). The isolated DNA-fragments were labelled with ${ }^{32} \mathrm{P}$ by nick-translation. 


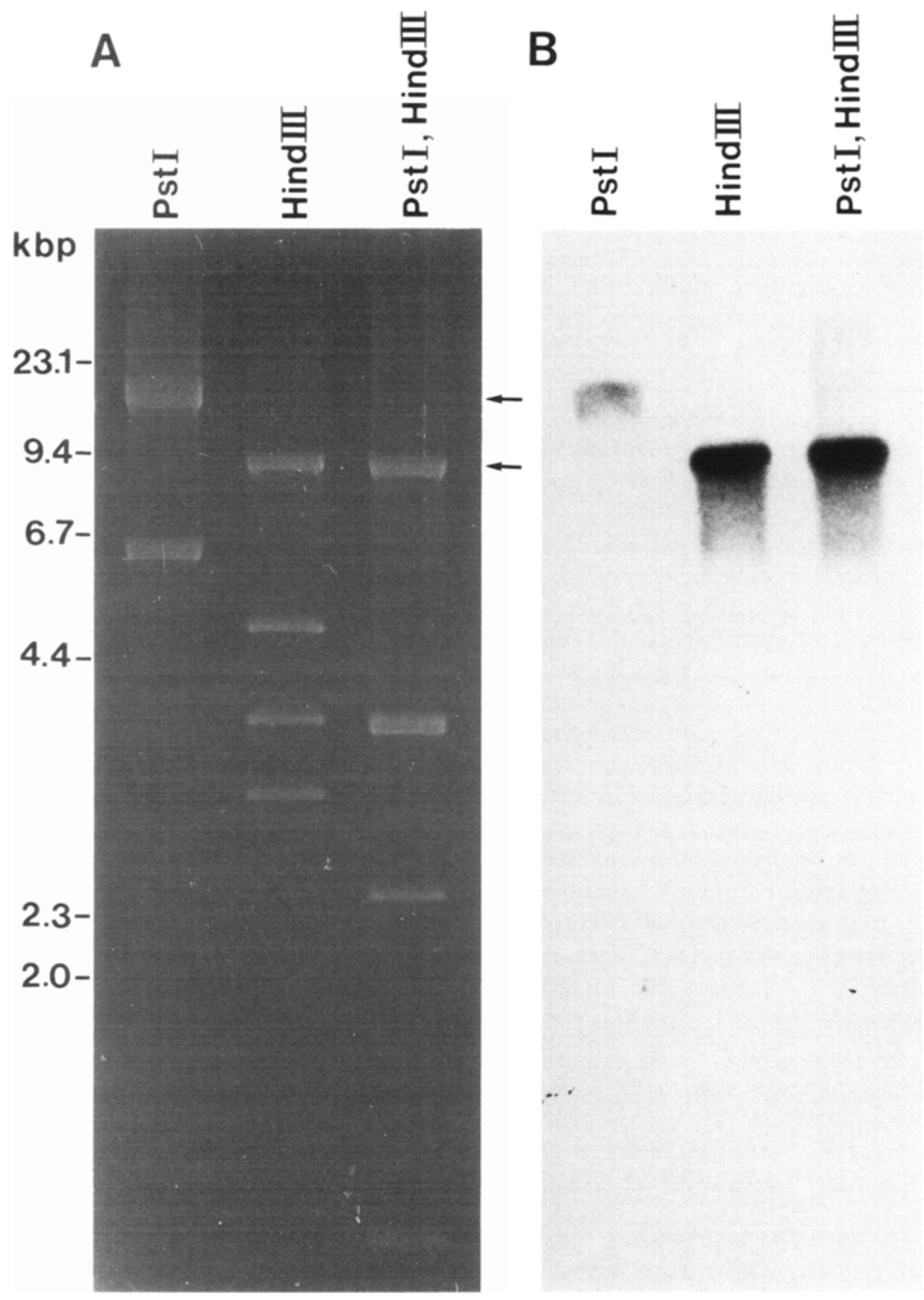

Figure 1. Localization of the psbE gene encoding cytochrome $b-559$ apoprotein I in the barley chloroplast genome. A psbE specific oligonucleotide hybridized to the barley chloroplast subclone pHvC 186. After digestion with PstI, HindIII, or PstI and HindIII the DNA fragments were separated electrophoretically on a $0.8 \%(\mathrm{w} / \mathrm{v})$ agarose gel and stained with ethidium bromide (A). After transfer to nitrocellulose DNA fragments were hybridized with the ${ }^{32}$ P-labelled oligonucleotide.

The autoradiogram is shown in panel B. Standard sizes are shown in kbp on the left and arrows indicate the hybridizing bands. 

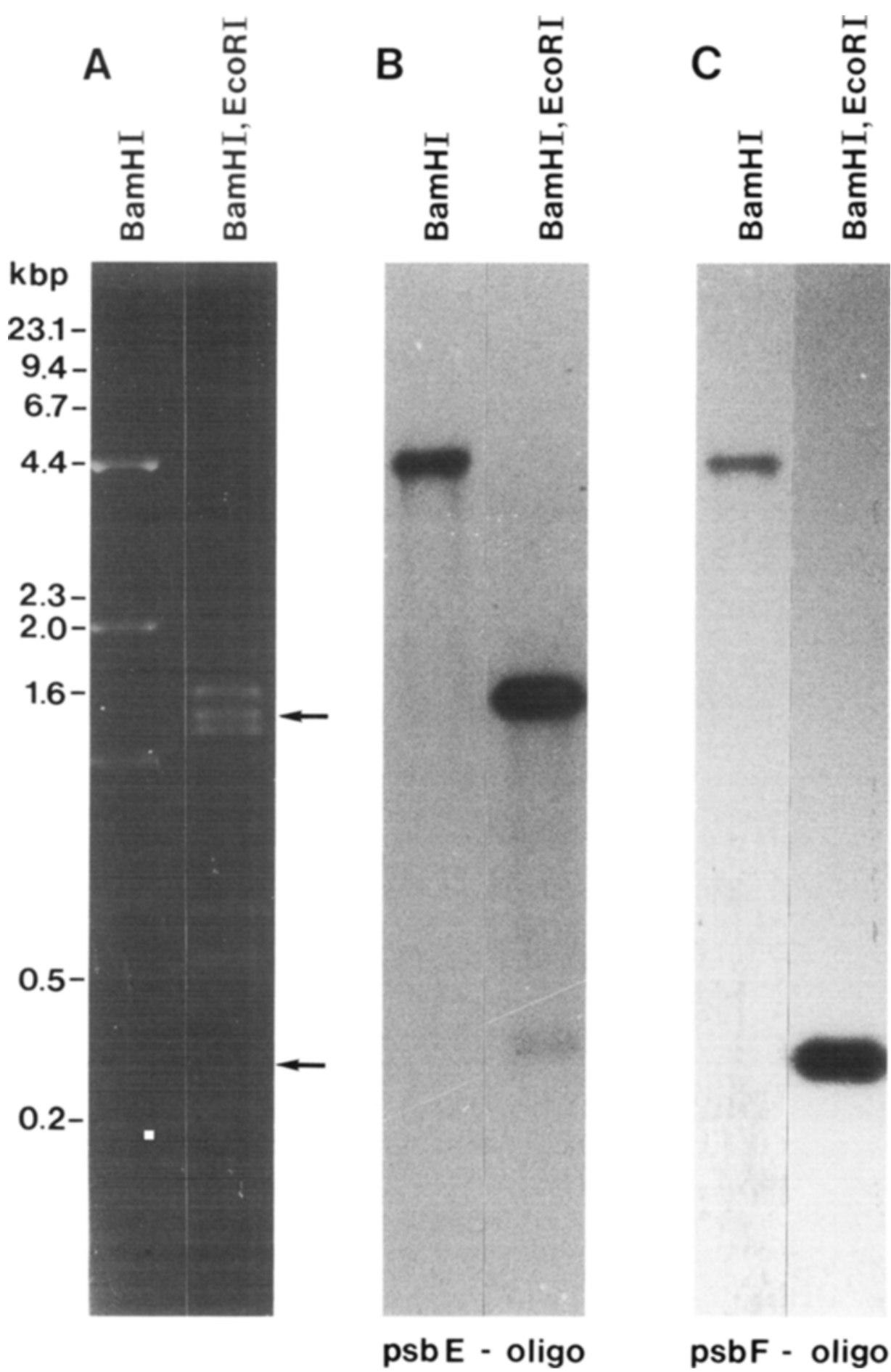
Figure 2. Localization of the barley psbF gene encoding cytochrome $b-559$ apoprotein II. ${ }^{32} \mathrm{P}$-labelled oligonucleotides specific for the psbE gene (B) and psbF gene (C) hybridize to the same DNA-fragment obtained by digesting the $8.3 \mathrm{kbp}$ HindIII insert of $\mathrm{pHvC} 46$ with BamHI but to different fragments after digestion with BamHI and EcoRI.

The fragments were separated electrophoretically on a $0.8 \%(w / v)$ agarose gel and were stained with ethidium bromide (A). After Southern blotting of the gel the fragments were hybridized with ${ }^{32} \mathrm{P}$-labelled psbE- and psbF-oligonucleotides. The autoradiograms are shown in panels $B$ and $C$, respectively.

Hybridizations were performed in a $6 \times \mathrm{SSC}$ and $0.1 \%(w / v)$ SDS containing $0.25 \%(w / v)$ solution of non-fat dry milk (Blotto = bovine lacto transfer technique optimizer) (14). The filters were washed twice with $2 \times$ SSC including $0.1 \%(w / v)$ SDS and once with $0.2 \times$ SSC including $0.1 \%(w / v)$ SDS. Autoradiography was carried out using Kodak X-Omat X-ray films with Kodak X-Omatic regular itensifying screens at $-80^{\circ} \mathrm{C}$.

\subsection{Analysis of RNA}

Chloroplast RNA was isolated from 12 hours illuminated barley seedlings as described earlier (3). The RNA was denatured and size fractionated by electrophoresis in a $1.5 \%(\mathrm{w} / \mathrm{v})$ agarose gel containing $20 \%(\mathrm{v} / \mathrm{v})$ formaldehyde with a buffer consisting of $40 \mathrm{mM}-\mathrm{MOPS}, 10 \mathrm{~mm}$-sodium acetate and 1 mM-EDTA, pH 7.2. The RNA was blotted onto nitrocellulose as described by MANIATIS et al. (17). For hybridization, the gene
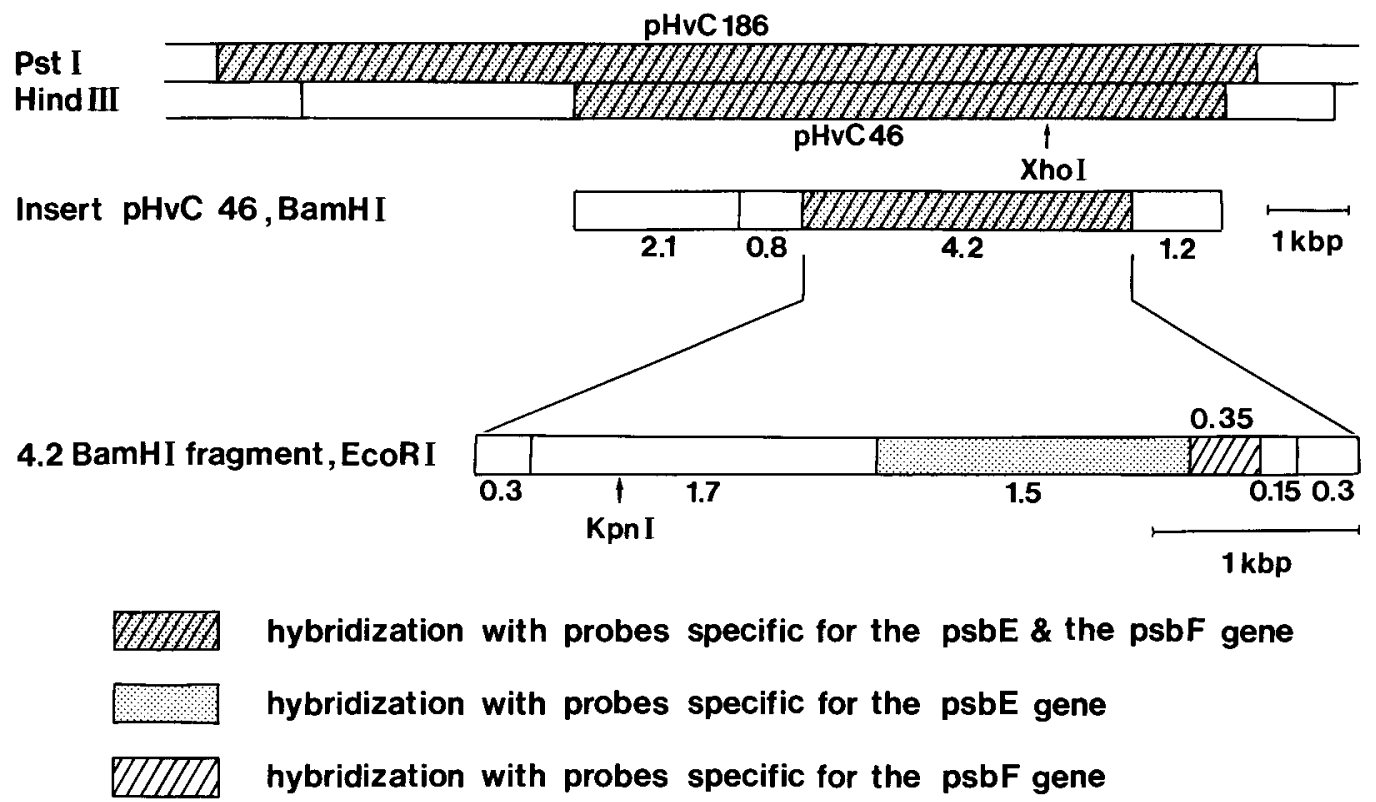

Figure 3. Physical map of the $13.5 \mathrm{kbp}$ PstI insert of pHvC 186. Only cleavage sites of enzymes relevant to localize the psbE and psbF genes are shown. The positions of endonuclease restriction sites were mapped according to (24) by labelling the DNA-fragments with ${ }^{32} \mathrm{P}$ at both ends and subsequently cleaving them into two asymmetrical subfragments. This was achieved for the $8.3 \mathrm{kbp}$ HindIII fragments with XhoI and for the $4.2 \mathrm{kbp} \mathrm{BamHI}$ fragment with KpnI. Arrows indicate the cleavage sites of these enzymes. The subfragments were partially digested with BamHI and EcoRI, respectively. The lengths of the fragments with a common labelled end reflect the positions of endonuclease restriction sites on the DNA. The positions of HindIII cleavage sites on the pHvC 186 insert had been determined by POULSEN (19). 
specific $1.5 \mathrm{kbp}$ EcoRI and $350 \mathrm{bp}$ EcoRI DNA-fragments (see 3.1 ) were labelled with ${ }^{32} \mathrm{P}$ according to the protocol of FEINBERG and VOGELSTEIN (8) using a mixture of hexadeoxyribonucleotides (Pharmacia) as primers.

Hybridization was carried out at $45{ }^{\circ} \mathrm{C}$ in $6 \times \mathrm{SSC}$ including $0.25 \%(\mathrm{w} / \mathrm{v})$ Blotto, $40 \%(\mathrm{v} / \mathrm{v})$ deionized formamide and $200 \mathrm{mM}$-phosphatebuffer, pH 6.5. Filters were subsequently washed with $2 \times \mathrm{SSC}$ and $0.2 \times \mathrm{SSC}$ at $50^{\circ} \mathrm{C}$, and exposed to Kodak X-Omat X-ray films at $-80^{\circ} \mathrm{C}$.

\section{RESULTS}

\subsection{Localization of the psbE- and psbF genes} on the chloroplast DNA of barley

PstI- and HindIII fragments of barley chloroplast DNA which had been cloned into the plasmids pBR325 and 322, respectively, (19) were separated on agarose gels, blotted onto nitrocellulose filters and probed with synthetic 18-mer oligonucleotides corresponding to sequences in the transcribed strand of the $\mathrm{psbE}$ and psbF genes of spinach (12). These sequences are indicated in Figure 6 by thin horizontal brackets. Both probes hybridized to the $13.5 \mathrm{kbp}$ PstI insert of pHvC 186 and to the $8.3 \mathrm{kbp}$ HindIII fragment (Figure 1). The HindIII fragment was obtained by digestion of the larger PstI fragment with HindIII and is also available as subclone pHvC 46 (19). The probes hybridized only to the $8.3 \mathrm{kbp}$ HindIII fragment but not to any adjacent HindIII fragment (Figure 1).

Digestion of the $8.3 \mathrm{kbp}$ HindIII fragment with BamHI released four subfragments of 4.2 $\mathrm{kbp}, 2.1 \mathrm{kbp}, 1.2 \mathrm{kbp}$ and $0.8 \mathrm{kbp}$ lengths (Figure 2A). Only the large $4.2 \mathrm{kbp}$ BamHI fragment hybridized with the probes specific for the psbE and psbF genes (Figure 2B, C) and hence contains both genes. EcoRI digestion of this fragment yielded five fragments of $1.5 \mathrm{kbp}, 1.2 \mathrm{kbp}$, $350 \mathrm{bp}, 2 \times 300 \mathrm{bp}$ and $150 \mathrm{bp}$ lengths (cf. Figure 3 ). The probe specific for the psbE gene hybridized only to the $1.5 \mathrm{kbp}$ fragment, while the probe specific for the psbF gene hybridized to the $350 \mathrm{bp}$ EcoRI fragment (Figure 2). Hybridizations with heterologous DNA from spinach (clones pCYb 559/1 and pCYb 559/2, kindly provided by R.G. HERRMANN) yielded analogous results (data not shown).
The positions of BamHI restriction sites within the $8.3 \mathrm{kbp} \mathrm{HindIII} \mathrm{insert} \mathrm{of} \mathrm{pHvC} 46$ and the positions of EcoRI restriction sites within the $4.2 \mathrm{kbp}$ BamHI fragment were mapped as described under 2.6 using XhoI and KpnI, respectively, to produce the asymmetric fragments. The results are summarized in Figure 3 and revealed that both genes are entirely included in the $4.2 \mathrm{kbp}$ BamHI fragment deriving from $\mathrm{pHvC} 46$.

\subsection{Transcript analysis}

Chloroplast RNA from illuminated barley seedlings was size fractionated on formamide containing agarose gels and blotted onto nitrocellulose filters. As probes the $1.5 \mathrm{kbp}$ EcoRI fragment which hybridizes to the psbE specific oligonucleotide, and the $350 \mathrm{bp}$ EcoRI fragment which hybridizes to the psbF specific oligonucleotide (Figures 2, 3) were used. As shown in Figure 4 both probes hybridized to the same RNA-species of $1.5 \mathrm{kbp}$ length.

\subsection{Characterization of the psbE- and psbF genes of barley}

For the nucleotide sequence analysis of the genes, the $1.5 \mathrm{kbp}$ EcoRI fragment and the 350 bp EcoRI fragment were subcloned into pUC13. A $330 \mathrm{bp}$ fragment isolated by AccI digestion of the $1.5 \mathrm{kbp}$ EcoRI fragment as well as a $490 \mathrm{bp}$ fragment including both genes and obtained by partial digestion of a $1.2 \mathrm{kbp} \mathrm{AccI-BamHI}$ fragment with Hinfl were also subcloned into pUC13 and used for sequencing. The relevant restriction sites and the sequencing strategy are shown in Figure 5.

The nucleotide sequence (Figure 6) reveals that the two adjacent genes are separated by an intercistronic region of only 10 nucleotides (excluding the stopcodon) which includes a putative ribosomal binding site, GGAGG (23) for the psbF gene at position -11. Another possible ribosomal binding site, GGAG, is located $10 \mathrm{bp}$ 5' upstream of the psbE-start codon. $110 \mathrm{bp} \mathrm{5}$ ' upstream of the psbE start codon a hexamer sequence identical with the procaryotic " -35 " promoter consensus sequence, TTGACA (21) can be identified. It is preceded and followed by other possible regulatory sequences. They are 


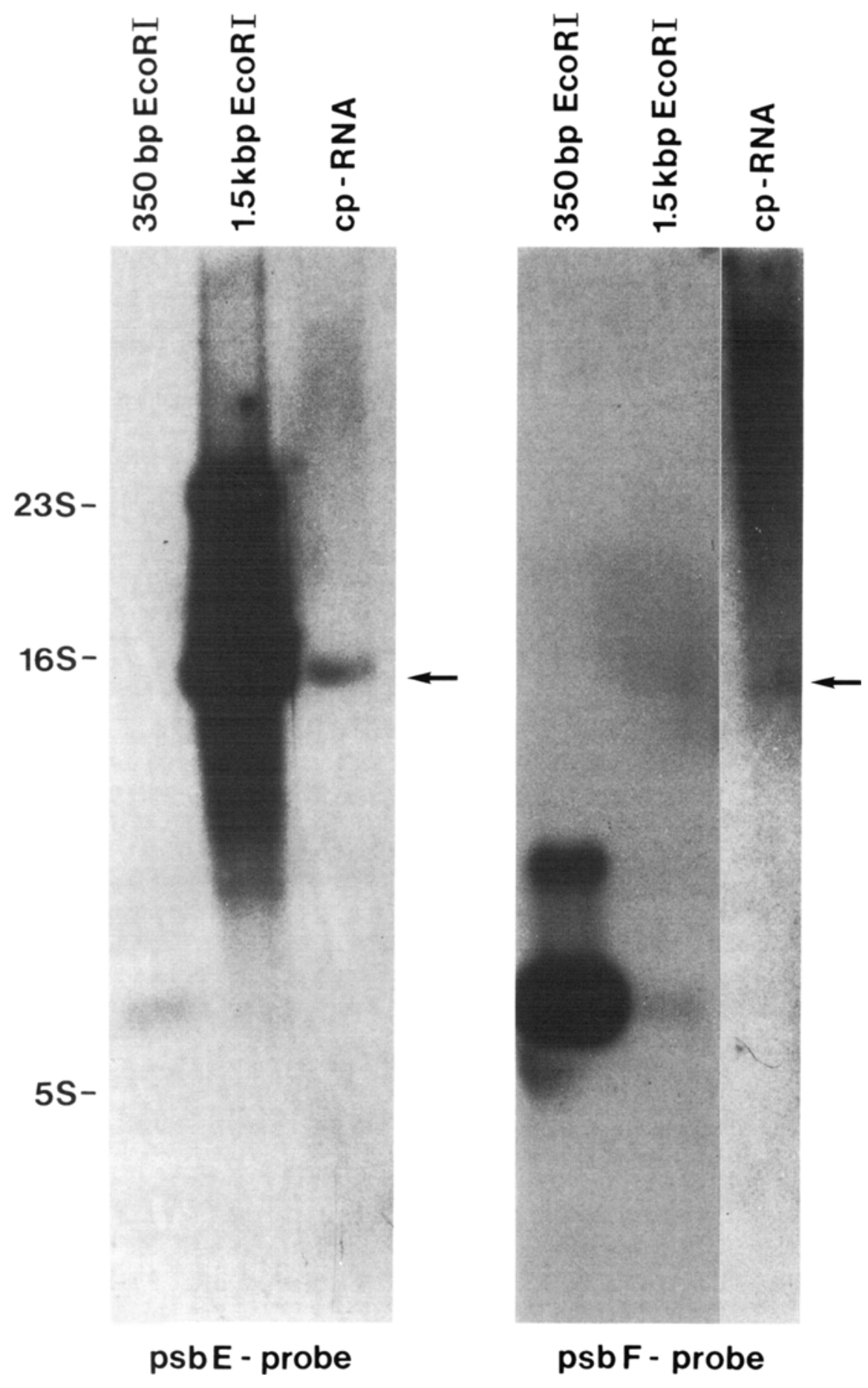


Figure 4. Autoradiogram of the "Northern" blot showing the common transcript of the psbE and psbF gene. Chloroplast RNA (cp RNA) from plants grown in the light was denatured, electrophoresed through a $1.5 \%$ (w/v) agarose gel containing $1 \%$ (w/v) MOPS, and blotted onto nitrocellulose. For comparison, a preparation enriched in the partly purified $350 \mathrm{bp}$ EcoRI fragment and a DNA preparation enriched in the $1.5 \mathrm{kbp}$ EcoRI fragment deriving from $\mathrm{pHvC} 46$ were electrophoresed through the same gel. After labelling with ${ }^{32} \mathrm{P}$ the $1.5 \mathrm{kbp}$ fragment was used as a probe specific for the psbE gene, and the $350 \mathrm{bp} \mathrm{EcoRI} \mathrm{fragment} \mathrm{was} \mathrm{used} \mathrm{as} \mathrm{a} \mathrm{probe} \mathrm{preferentially}$ hybridizing to the psbF gene. Hybridization was carried out in the presence of $40 \%(\mathrm{v} / \mathrm{v})$ formamide, $0.25 \%(\mathrm{w} / \mathrm{v})$ Blotto (14), 6xSSC and $50 \mathrm{~mm}$-sodium phosphate buffer $(\mathrm{pH} 6.5)$ at $45^{\circ} \mathrm{C}$. The arrow on the right indicates the hybridizing RNA band. E. coli rRNA size standards of 23 S rRNA (2904 nucleotides), 16 S rRNA (1541 nucleotides) and $5 \mathrm{~S}$ rRNA (120 nucleotides) (Boehringer, Mannhein) are shown on the left.

underlined in Figure 6 and compared with similar sequences of other plant species in Figure 7.

\section{DISCUSSION}

The cytochrome $b-559$ encoding genes psbE and psbF of barley are located at equivalent positions on the chloroplast DNA as in spinach and other dicotyledones (5) as well as in wheat (13). The positions of the genes in the large single copy region adjacent to the gene for cytochrome $f$ are indicated on the physical map of barley chloroplast DNA illustrated by SøGAARD and $v$. WETTSTEIN-KNOWLES (26).

In all cases an EcoRI restriction site in the terminal part of psbE facilitates sequencing of the two genes. PsbE and psbF of barley are separated by 10 nucleotides. While the length of this intercistronic region is the same in the case of wheat, it spans only 8 nucleotides in spinach (12) and 9 nucleotides in Oenothera and tobacco (5). The TAG termination codon of psbE overlaps the putative ribosomal binding site, GGAGG (23) of psbF, in all plant species investigated so far. Also the psbE gene is consistently preceded by a similar sequence, GAGG which might function as a ribosomal binding site for this gene.

The nucleotide sequences of the psbE and psbF genes of barley are identical with those of wheat (13) and are more than $95 \%$ similar with those of spinach, tobacco and Oenothera (5). Likewise, the non-coding regions of the sequence 5' upstream of psbE and 3' downstream of psbF in barley are almost identical to those available in wheat. Only one " $\mathrm{C}$ " in position 451 (Figure 6) is exchanged by a " $\mathrm{G}$ " in wheat (13).
A comparison of the non-coding region 5 ' upstream of the barley psbE gene (Figure 6) with those of spinach and Oenothera (5) reveals quite high similarity until about position -60. Except for possible regulatory sequences, no homology is detectable further upstream. In the 3' downstream region of psbF the barley sequence shows no homology with the corresponding sequence of spinach (12).

In the 5' upstream region of the barley psbE gene are located possible regulatory sequences (Figures 6, 7) resembling the procaryotic "-35" and "-10" promoter consensus sequences (21). Interestingly, in barley two promoter-like “-35" sequences are arranged close to each other. The first heptamer sequence starting at position -121 , TTGGTAC, appears also in the sequence 5 ' upstream of the spinach psbE gene (12). The second promoter-like "-35" sequence in barley,

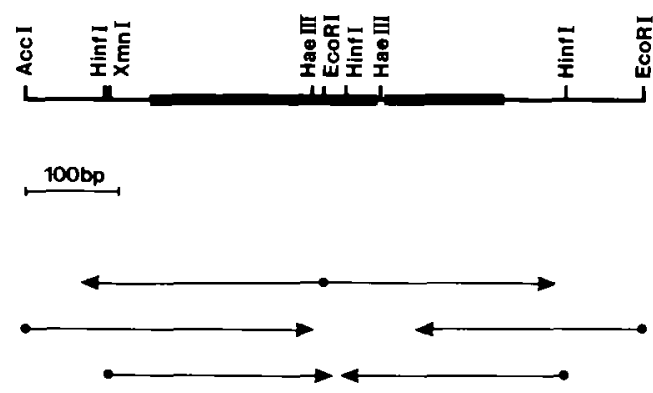

Figure 5. Sequencing strategy of the 350 bp EcoRI fragment and part of the neighbouring $1.5 \mathrm{kbp} \mathrm{EcoRI}$ fragment. All fragments indicated were subcloned into the double-stranded vector pUC13 and sequenced by the dideoxy chain termination method of SANGER et al. (22) using direct and reverse primers. 


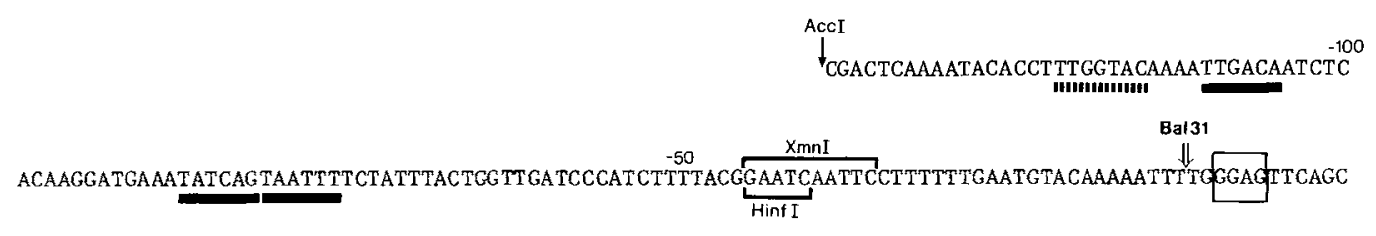

ATG TCT GGA AGC ACG GGA GAA CGT TCT TTT GCT GAT ATT ATT ACC AGT ATT CGA TAC TGG GTT ATT CAT AGC ATT Met Ser Giy Ser Thr Gly Glu Arg Ser Phe Ala Asp Ile Ile Thr Ser Ile Arg Tyr Trp Val Ile His Ser Ile

ACT ATA CCT TCC CTA TTC ATT GCG 100 GGT TGG TTA TTT GTC AGT ACG GGT TTA GCT TAT GAC GTG TTT GGA AGT CCT Thr Ile Pro Ser Leu Phe Ile Ala Gly Trp Leu Phe Val Ser Thr Gly Leu Ala Tyr Asp VaI Phe Gly Ser Pro Hae II
AGG CCA AAC GAG TAT TTC ACG GAA AGC CGA CAA GGA ATT CCG TTA ATA ACC GAC CGT TTT GAT TCT TTA GAA CAA
Arg Pro Asn Glu Tyr Phe Thr Glu Ser Arg Gln Gly Ile Pro leu Ile Thr Asp Arg Phe Asp Ser Leu Glu Gln

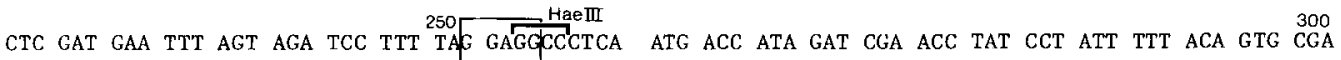
Leu Asp Glu Phe Ser Arg Ser Phe Met Thr Ile Asp Arg Thr Tyr Pro Ile Phe Thr Val Arg

TGg CTG GCT ATT CAC GGA CTA GCT GTA CCT ACT GTT TTT TTC TTG GGa TCA aTA tCA GCA atg CAG tTC ATC CAA Trp Leu Ala Ile His Gly|Leu Ala Val pro Thr Val Phe Phe Leu Gly Ser Ile Ser Ala Met Glu Phe Ile Gln

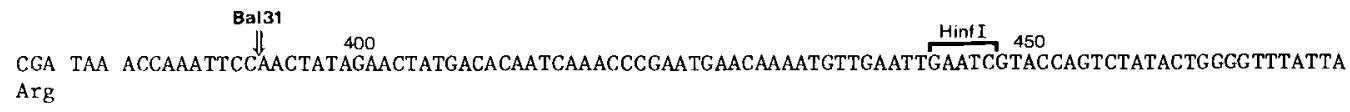
$\stackrel{500}{500}$ CTCATTTTTGTACTTGCTGTTTTATTCAATTACTTCTTCAATTGAGAGAAAGAAAGAGACTAACAAG

Figure 6. Nucleotide sequence of the $350 \mathrm{bp}$ EcoRI fragment and the neighbouring $330 \mathrm{bp}$ Accl-EcoRI fragment derived from the larger $1.5 \mathrm{kbp}$ EcoRI fragment. The nucleotides of the non-transcribed strand of the genes are arranged in codons corresponding to the derived amino acid sequence of the proteins. Numbering starts at the first base of the psbE start codon. Putative ribosomal binding sites are boxed and relevant endonuclease restriction sites indicated by horizontal brackets or at the start and end of the sequence by arrows. Double-lined arrows indicate the positions up to which non-coding sequences adjacent to the genes were degraded by Bal 31 exonuclease treatment in preparation for in vitro expression studies. Sequences underlined by thin horizontal brackets are complementary to the synthetic oligonucleotides used as probes for the $p s b E$ and $p s b F$ genes. Potential promotor-like sequences are underlined.

TTGACA, starting at position -110 , is identical with the canonical "- 35 " consensus sequence of procaryotic promoters $(21)$. This hexamer is followed at a distance of $17 \mathrm{bp}$ by another hexanucleotide, TATCAG, and at a distance of 23 bp by the hexanucleotide TATTTT (Figures $6,7)$. Although one cannot exclude a regulatory function of the first promoter-like "-35" sequence we assume that the TTGACA hexamer together with the 17 bp downstream TATCAG sequence constitutes a promoter. Since the distance between the two promoter-like sequences in chloroplasts can vary from 11 to 24 bases (16) it is also feasible that the TATTTT hexamer which is separated by 23 bp from the " -35 " sequence constitutes the second part of a putative promoter. While in the first case the spacing between the relevant hexanucleotides is optimal (17 bp), in the second case the "-10" region contains the canonical " $T$ " in the last position 


\section{$-120$ \\ 1 \\ Barley \\ TIIGGTACAAAATTGACAATCTCACAAGGATGAAATATCAGTAATTT \\ Spinach TTTGGTACTATATTGGCAATCCTACAAGTATTTTACGTTTTTACGTG \\ Denothera GTTATACTCATTAGCTCTATACTGATTCGGTATACTCGAAAAACACC}

Figure 7. Possible regulatory sequences resembling the procaryotic "-10" and "- -35 " promotor consensus sequences (21) in the 5' upstream region of the psbF genes of barley, spinach and Oenothera. The corresponding heptamer and hexamer sequences are underlined. A second possible regulatory sequence preceding the procaryotic like "-35" hexamer TTGACA in barley is indicated by a broken line. Numbering is only valid for the barley sequence.

(21). However, promoter-like structures of a few other chloroplast genes lack a " $T$ " in this position (16). Expression of chloroplast genes in a homologous in vitro system has been found to be more efficient with the TTGACA hexamer than with similar sequences containing altered bases (9).

The possible regulatory sequences 5 ' upstream of the barley psbE gene are lined up with corresponding sequences of spinach and Oenothera (5) in Figure 7. In spinach the TTGGTAC heptamer is followed at a distance of 14 bp by a TACAAG hexamer, and in Oenothera a TTATAC starting at position - 159 is separated by $23 \mathrm{bp}$ from the hexamer sequence TATACT. The possibility to deduce two different promoter-like structures from the nucleotide sequence seems to be unique to barley.

Whether these sequences resembling procaryotic promoter structures are really used by the homologous RNA-polymerase is still unclear (10). Nevertheless, they probably do serve as promoters for E. coli RNA polymerase which is often used in studies on the expression of chloroplast genes.

The start of transcription has not yet been determined for the psbE and psbF genes of barley. In spinach and Oenothera the probable transcription initiation sites are located at appropriate positions behind the promoter-like sequences (5). "Nothern" blot analysis revealed that in barley both genes are transcribed into a common single RNA species of $1.5 \mathrm{kbp}$ length (Figure 4). Initially, a single RNA of $1.1 \mathrm{kbp}$ length was described for the two genes in spinach
(29). Later studies with spinach, Oenothera and tobacco (5) revealed a minor $1.7 \mathrm{kbp}$ long transcript in addition to the prominent $1.1 \mathrm{kbp}$ transcript. The results obtained by "Nothern" blot analysis clearly show that psbE and psbF are co-transcribed, which may facilitate the 1:1 stoichiometry of the 9.4 and $4.4 \mathrm{kD}$ apoproteins as observed in spinach (31) and support the heterodimer model for cytochrome $b-559$ (12).

However, the existence of two separate putative ribosomal binding sites preceding the psbEand $\mathrm{psbF}$ genes prompts the question whether both proteins might be synthesized independently, and how such an independent expression on the translational level might be regulated. Since no protein precursor containing both polypeptides has been detected until now, an independent translation of the two apoproteins is conceivable. One can speculate that the stoichiometry of the two apoproteins might influence the function of cytochrome $b-559$. Results obtained with a coordinate and an independent in vitro expression of the barley psbE- and psbF genes are described in a forthcoming paper in this journal.

\section{ACKNOWLEDGEMENTS}

We would like to thank Professor DITER vON WETTSTEIN for stimulating discussions and critical review of the manuscript. We are indebted to Dr. ELIZABETH JACKSON for synthesis of the oligomers. NINA RASMUSSEN is thanked for drawing the figures. We also thank GuNILLA 
Hgyer-Hansen, Hanne Them Nielsen and Professor DiTER vON WETTSTEIN for technical help during preparation of the manuscript. The work was supported by an EMBO Fellowship to KARIN KRUPINSKA and a U.S. National Science Foundation Fellowship in Plant Biology to SANDY BERRY-LowE.

\section{REFERENCES}

1. Babcock. G.T., W.R. Widger, W.A. Cramer, W. OERTLING \& J.G. METZ: Axial ligands of chloroplast cytochrome b-559: identification and requirement for a heme-cross-linked polypeptide structure. Biochem. 24, 3638-3645 (1985)

2. Bassi, R., G. Høyer-Hansen, R. Barbato, B.M. GIACOMETTI \& D.J. SIMPSON: Chlorophyll-proteins of the photosystem II antenna system. J. Biol. Chem. 262, 13333-13341 (1987)

3. BERRY-LOWE. S.: The chloroplast glutamate tRNA gene required for $\delta$-aminolevulinate synthesis. Carlsberg Res. Commun. 52, 197-210 (1987)

4. Birnboim, H.C. \& J. Doly: A rapid alkaline extraction procedure for screening recombinant plasmid DNA. Nucleic Acids Res. 7, 1513-1523 (1979)

5. Carillo, N.,P.Seyer, A. Tyagi \& R.G. HerrmanN: Cytochrome b-559 genes from Oenothera hookeri and Nicotiana tabacum show a remarkably high degree of conservation as compared to spinach. Current Genet. 10, 619-624 (1986)

6. Chen. E.Y. \& P.H.SeEbuRG: Supercoil sequencing: a fast and simple method for sequencing plasmid DNA. DNA 4, 165-170 (1985)

7. CRamer, W.A.. J. Whitmarsh \& W. Widger: On the properties and function of cytochrome b-559 and $f$ in chloroplast electron transport. In: Proceed. of the 5th Intern. Photosynthesis Congress. Photosynthesis. G. Akoyunoglou ed., Balaban International Science Services, Philadelphia, Vol. II, pp. 509-522 (1981)

8. FEInBERG, A.P. \& B. VOGELSTEIN: Radiolabeling DNA restriction endonuclease fragments to high specific activity. Anal. Biochem. 132, 6-13 (1983)

9. Gruissem. W. \& G. ZurawsKI: Analysis of promoter regions for the spinach chloroplast $\mathrm{rbcL}$, atpB and psbA genes. EMBO J. 4, 3375-3383 (1985)

10. Hanley-Bowdoin, L. \& N.-H. Chua: Chloroplast promoters. Trends in Biochem. Science 12, 67-70 (1987)

11. Hattori. M. \& Y. SAKaKI: Dideoxy sequencing method using denatured plasmid templates. Anal. Biochem. 152, 232-238 (1986)

12. Herrmann, R.G., J. Alt, B. Schiller, W.R.
Widger \& W.A. Cramer: Nucleotide sequence of the gene for apocytochrome b-559 on the spinach plastid chromosome: implications for the structure of the membrane protein. FEBS Lett. 176, 239-244 (1984)

13. Hird, S.M. D.L. Willey, T.A. DYer \& J.C. Gray: Location and nucleotide sequence of the gene for cytochrome b-559 in wheat chloroplast DNA. Mol. Gen. Genet. 203, 95-100 (1986)

14. Johnson, D.A., J.W. Gautsch. J.R. SPORTSMAN \& J.H. ELDER: Improved technique utilizing nonfat dry milk for analysis of proteins and nucleic acids transferred to nitrocellulose. Gene Anal. Tech. 1, 3-8 (1984)

15. KOENIG. F.\& B.L. MøLLER: Isolation and characterization of cytochrome $b-559$ from chloroplasts and etioplasts of barley. Carlsberg Res. Commun. 47, 245-262 (1982)

16. KUNG, S.D. \& C.M. LiN: Chloroplast promoters from higher plants. Nucleic Acids Res. 13, 75437549 (1985)

17. Maniatis, T., E.F. Fritsch \& J. Sambrook: Molecular cloning. Cold Spring Harbor Laboratory Press, New York (1982)

18. NANBA, O.\& K. SATOH: Isolation of a photosystem II reaction center consisting of D-1 and D-2 polypeptides and cytochrome b-559. Proc. Nat. Acad. Sci. USA 84, 109-112 (1987)

19. POULSEN.C.: The barley chloroplast genome: physical structure and transcriptional activity in vivo. Carlsberg Res. Commun. 48, 57-80 (1983)

20. Radloff, R., W. Bauer \& J. VINOGRaD: A dyebuoyant-density method for the detection and isolation of closed circular duplex DNA: the closed circular DNA in HELA cells. Proc. Nat. Acad. Sci. USA 57, 1514-1524 (1967)

21. RosenberG, M. \& D. CoURT: Regulatory sequences involved in the promotionand termination of RNA transcription. Ann. Rev. Genet. 13, 319-353 (1979)

22. Sanger. F., S. NiCklen \& A.R. Coulson: DNA sequencing with chain-terminating inhibitors. Proc. Nat. Scad. Sci. USA 74, 5463-5467 (1977)

23. SHine, J. \& L. DalgaRno: The 3'-terminal sequence of Escherichia coli 16 S ribosomal RNA: Complementarity to nonsense triplets and ribosome binding sites. Proc. Nat. Acad. Sci. USA 71, 1342-1346 (1974)

24. Smith. H.O. \& M.L. Birnstiel: A simple method for DNA restriction site mapping. Nucleic Acids Res. 3, 2387-2398 (1976)

25. Southern, E.M.: Detection of specific sequences among DNA fragments separated by gel electrophoresis. J. Mol. Biol. 98, 503-517 (1975)

26. SrgaARD. B. \& P. v. Wettstein.Knowles: Barley: 
Genes and chromosomes. Carlsberg Res. Commun. 52, 123-196 (1987)

27. VieIRA.J.\&J.Messing: The pUC plasmids, an M13 $\mathrm{mp}^{7}$-derived system for insertion mutagenesis and sequencing with synthetic universal primers. Gene 19, 259-268 (1982)

28. WassermanN, A.R.: Chloroplast cytochromes $f$, b-559 and b-6. In: Methods in Enzymology $69 \mathrm{C}$. A. San Pietro ed., Academic Press, New York, pp. 181-201 (1980)

29. Westhoff, P., J. Alt. W.R. Widger, W.A. Cramer \& R.G. HerrmanN: Localization of the gene for apocytochrome b-559 on the plastid chromosome of spinach. Plant Mol. Biol. 4, 103-110 (1985)

30. Widger, W.R., W.A. Cramer, M. Hermodson, D. MeYer \& M. GULlifor: Purification and partial sequence of the chloroplast cytochrome b-559. J. Biol. Chem. 259, 3870-3876 (1984)

31. Widger, W.R., W.A. Cramer, M. Hermodson \& R.G.HERRMANN: Evidence for a hetero-oligomeric structure of the chloroplast cytochrome b-559. FEBS Lett. 191, 186-190 (1985)

32. ZIELINSKI, R.E.\& C.A. PRICE: Synthesis of thylakoid membrane proteins by chloroplasts isolated from spinach. Cytochrome b-559 and P700-chlorophyll a-protein. J. Cell Biol. 85, 435-445 (1980)

Accepted by H. KLENOw 